\title{
ANALYSIS OF FACTORS INFLUENCING THE INTENTION TO USE BANK SYARIAH INDONESIA MOBILE BANKING WITH TRUST AS MEDIATION
}

\author{
Nindya Mustika ${ }^{1}$ and Rosana Eri Puspita ${ }^{2}$ \\ ${ }^{1}$ Sharia Banking Program, IAIN Salatiga \\ ${ }^{2}$ Sharia Business Management, IAIN Salatiga \\ rosana.eri.p@iainsalatiga.ac.id
}

\begin{abstract}
This research is motivated by the problems that occur around students on Campus that they have a bank account in Bank Syariah Indonesia (BSI), but they have not mobile banking. This study has three independent variables, one dependent variable, and one mediating variable. This study investigates how perceived convenience, availability of Islamic features and risk perception are on intention-to-use BSI mobile banking with trust as the mediating variable. The grand theory of this study is the Technology Acceptance Model (TAM). The population is 3,650 students of the Islamic Business and Economics Faculty of IAIN Salatiga. The sample was taken by distributing questionnaires through purposive sampling technique. A criterion had been determined previously and was calculated using the Slovin formula so that the number of samples was 360 samples. The data was processed with IBM SPSS 23 and then analyzed using instrument tests, hypothesis testing, classical assumption tests, and path analysis. The first (partial) $t$-test shows that the perceived convenience variable and the availability of Islamic features have a significant positive effect on trustworthiness. In contrast, risk perception has a significant negative effect on trustworthiness. The second t-test results show the same results as the previous t-test for the intention-to-use BSI mobile banking. The path analysis results also show that the trust variable can mediate the perceived convenience, the availability of Islamic features, and the risk perception of the intention to use BSI mobile banking.
\end{abstract}

Keywords: Mobile banking, Technology Acceptance Model, intention, millennial, BSI

\section{INTRODUCTION}

Technological advances are developing rapidly, causing the emergence of various technological innovations that are increasingly sophisticated, where something complicated can easily be found. One of the technologies known in the banking world is mobile banking. Mobile banking is a banking service that can be used to make transactions via smartphones or commonly referred to as smartphones (Tampubolon, 2015).

Based on the Jenius Financial Study results with Indonesia Digital Savvy Behavior's theme, it was stated that mobile banking users grew from 28\% in 2014 to $30 \%$ in 2018 (Bareksa, 2019). Meanwhile, the Financial Services Authority, through detikFinance, explained that in 2020 , around $80 \%$ of banking transactions were carried out via cell phones 
(mobile banking) (Laucereno, 2019). Today's Indonesian people prefer something instant; it doesn't take long; the service is fast and cheap. The selection of a mobile banking service can be based on pricing, security, and innovation. Besides being profitable for customers, digitalization can also make banking more efficient by $20-30 \%$.

According to research, mobile banking is influenced by several factors or causes, including ease of use, benefits, trust, access ability, and risks (Hadi \& Novi, 2015). In this research, three independent variables were used: perceived ease of use, availability of Islamic features and perceived risk. Many studies have shown that perceived convenience affects customers' trust and intention. As research conducted by (Rahmad, Astuti, \& Riyadi, 2017), shows a positive influence between the perceived convenience variable on mobile banking trust. A study also showed a positive influence between perceived ease of use and intention to use mobile banking (Gunawan, 2014). Likewise, according to other studies, the feature availability variable suggests a positive influence between feature availability on trust and intention in mobile banking (Afifah, 2017; Riyanto, 2018). The risk perception variable showed a negative influence between risk perception variables on trust and intention in mobile banking (Aieni \& Purwantini, 2017; Ashur, 2016). As an intervening variable, trust also significantly affects intention, positively influencing the two variables (Amelia, 2017).

The research was conducted because of a phenomenon found in the Islamic Business and Economics Faculty of IAIN Salatiga. From the exploratory studies that have been carried out, it is found that all students have and use a BSI account (initially BRI Syariah KC MT. Haryono Semarang) because it is a mandatory account from the Campus. Still, most of them do not have BSI mobile banking. This can be seen in Table 1.

Table 1

Exploratory Study Data

\begin{tabular}{lcc}
\hline \multicolumn{1}{c}{ Study Program } & BSI Customers & Mobile Banking Users \\
\hline Islamic Banking & 42 & 12 \\
\hline Islamic Economics & 4 & 2 \\
\hline Islamic Accounting & 2 & 1 \\
\hline $\begin{array}{l}\text { Sharia Business } \\
\text { Management }\end{array}$ & 2 & 1 \\
\hline \multicolumn{1}{c}{ Total } & $\mathbf{5 0}$ & $\mathbf{1 6}$ \\
\hline
\end{tabular}

Source: Primary data processed, 2020

From a survey conducted on 50 students of the Islamic Business and Economics Faculty of IAIN Salatiga, only 16 respondents (32\%) own and use BSI mobile banking. In contrast, the remaining 34 respondents $(68 \%)$ do not use the service. They are more intent to use ATMs and teller services than mobile banking. However, the mobile banking application can play a role by providing various facilities for students to carry out banking transactions, such as paying UKT (Single Tuition Fee) every semester. 
From the result of exploratory study and differentiation of the previous research on each variable, it can be concluded that there is still a gap. This study examines the factors that can influence student intention in using mobile banking through perceived convenience, availability of Islamic features, and perceived risk with trust as an intervening variable.

\section{Literature Review}

\section{Technology Acceptance Model (TAM)}

The Technology Acceptance Model (TAM) is based on the Theory of Reasoned Action (TRA) proposed by Ajzen and Fishbein in 1980. TAM plays a role in understanding the factors that can influence someone in accepting computer technology, and someone will use this technology if they know positive benefits from their use (Thompson, Higgins, \& Howell, 1991). In this case, TAM is associated with students' acceptance from the Islamic Business and Economics Faculty of IAIN Salatiga to the BSI mobile banking technology.

\section{Mobile Banking}

Mobile banking can be defined as a banking channel where customers can use their cell phones to carry out banking transactions or other financial services except to take cash (Audi, 2016). There are two forms of mobile banking, namely SMS-banking, which is accessed by sending written messages and WAP-banking, a form of mobile internet service accessed via a GPRS (internet) connection. With mobile banking services, banking transactions usually done manually by visiting the bank can now be done only by using a cellphone so that customers can save time and costs (Mubiyantoro \& Syaefullah, 2013). The mobile banking that will be examined in this research is a service issued by BSI. With the various facilities available, it can attract students from the Islamic Business and Economics Faculty of IAIN Salatiga or vice versa.

\section{Perceived Ease of Use}

Perceived ease of use can be interpreted as a perception in which someone believes that technology is quite easy and does not require hard effort from users (free for effort) (Ahmad \& Pambudi, 2013). Thus, if banking services are perceived as being easy to use by customers, these services will also be perceived as useful (Davis, 1989). Likewise, with this research study, if students' perceived ease of use (customers) towards BSI mobile banking is high, mobile banking is useful and has a positive value.

\section{Availability of Islamic Features}

Features are equipment for customer interactivity and essential criteria that attract customers' attention in delivering internet banking services (Pranidana, 2009). Customers prefer to use updated mobile banking or have various new features that have been improved (Williams, 2011). 
This research will focus on examining the availability of Islamic features found in BSI mobile banking. Product innovation can be associated with the availability of adequate technology, the introduction of the right product, and services development (Ong, Hong, Teh, Soh, \& Tan, 2014). The innovations made by Islamic banking in its mobile banking services related to Islamic features include:

\section{Table 2}

\section{Islamic Features of BSI Mobile Banking}

\begin{tabular}{ll}
\hline No & \multicolumn{1}{c}{ Features } \\
\hline 1 & $\begin{array}{l}\text { Donasi (BAZNAZ, Dompet Dhuafa, Griya Yatim, Rumah Zakat, ZIS } \\
\text { BSI, LazizNU, dll) }\end{array}$ \\
\hline 2 & Informasi Waktu Shalat \\
\hline 3 & Penunjuk Arah Kiblat \\
\hline 4 & Lokasi Masjid Terdekat \\
\hline 5 & Juz,Amma \\
\hline & Source: (BRI Syariah Web, 2020)
\end{tabular}

These features can provide added value because they are not found in other mobile banking banks, especially conventional banks. With this innovation, it is hoped that it can attract customers to have more mobile banking confidence. In addition to being a partner, BSI also maintains its mandate as sharia-based banking by providing Islamic features.

\section{Perceived Risk}

The definition of risk perception is that there is a belief in uncertainty that can create opportunities for loss for decision-makers (Muslich, 2009). Concerning the e-banking facility, which is considered an effective and efficient technology, e-banking is also not free from risks. The Financial Services Authority (OJK) mentions two things prone to occur in mobile banking: theft and piracy of the user's PIN and cellphone number (Otoritas Jasa Keuangan, 2015). For this reason, the lower the perceived risk perception of customers in using mobile banking, the higher the intention in using the service. In this study, risk perception can be defined as customers' beliefs about potential negative results using BSI mobile banking.

\section{Trust}

Trust is a condition in which a person can accept reality based on positive expectations of the desire or goal of something he believes in (Rousseau, 2009). The trust factor is very important in transactions that involve technology such as mobile banking. This study's trust concept means customers can rely on BSI mobile banking technology to provide security for users. Security in the form of a sense of security when using it, the risk of losing data or information is very small, and the risk of theft is very small.

\section{Intention}


Behavioural intention is a desire that an individual has to do something. This means that when an individual is intentioned in doing something, it can be seen from his behaviour and how he believes in others (Jogiyanto, 2007). Specifically, the intention referred to is the intention in using mobile banking facilities. Intention-to-use of technology is measured by the proportion of technology users use in choosing to utilize the system. The use of technology takes place in a voluntary situation (Amijaya, 2010). If associated with this research, intention means the tendency of students of the Islamic Economics and Business Faculty of IAIN Salatiga to act before deciding to use the BSI mobile banking service.

\section{Research Framework}

Picture 1

Research Framework

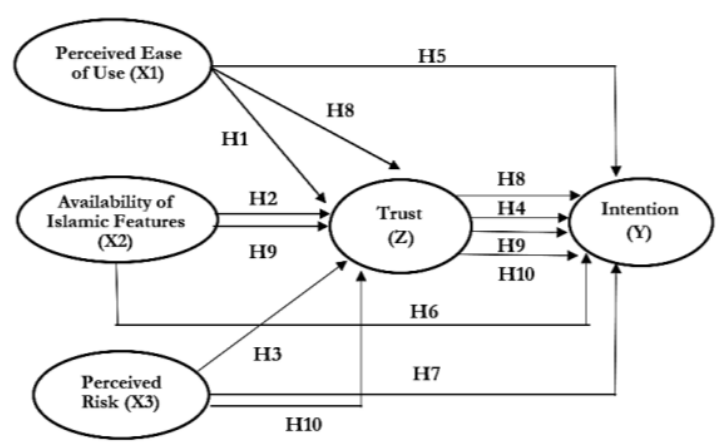

\section{Research Methods}

The type of research used in this research is field research, a method used in research by observing phenomena in the environment (Sunyoto, 2016). Therefore, data collection in this study was carried out directly in the field by distributing questionnaires to respondents. The approach used is quantitative, which is data in the form of numbers or numbers. Following its form, quantitative data can be processed or analyzed using mathematical and statistical calculation techniques (Bisri, 2001).

The population is all data that concerns researchers within a predetermined timeframe (Zuriah, 2009). In this study, the object that became the population was active students of the Islamic Economics and Business Faculty of IAIN Salatiga, BSI customers totalling 3,650 people (1,532 Islamic Banking, 962 Islamic Economics, 641 Sharia Business Management, and 515 Islamic Accounting).

The sample is part of the population whose characteristics are to be studied (Djarwanto, 2001). A good sample is a representative, or that can describe the characteristics of the population taken. In this study, a purposive sampling technique was used, in which the sampling process was carried out by considering the previously known characteristics (Notoatmodjo, 2010).

The sample in this study has four criteria. First, they are an active student of the Faculty of Economics and Islamic Business IAIN Salatiga. Second, customers of BSI. 
Third, not yet using BSI mobile banking. And the last, smartphone users connected to the internet. From the population above, the sample is calculated using the Slovin formula so that the following results are found 360 sample. Data collection methods are techniques or methods used by researchers to obtain data analyzed or processed to produce a conclusion (Bawono, 2006). The techniques used to collect various data in this study are through questionnaires, observation, and literature.

The measurement scale used is a Likert scale. The Likert scale is used to measure attitudes, opinions and perceptions of a person or group regarding social phenomena. With a Likert scale, the variables to be measured are translated into indicators. The indicator is then used as a benchmark for compiling instrument items that can be in the form of questions or statements. The respondent will select the instrument items in the form of approval or disagreement with the statement submitted. The scores of each Likert scale in this study are 1 (Strongly Disagree), 2 (Disagree), 3 (Neutral), 4 (Agree), 5 (Strongly Agree).

The research instrument was tested using validity and reliability test. The validity test used in measuring whether a questionnaire is valid or not is the validity test. The validity test in this study uses the Product Moment correlation formula. If $\mathrm{r}$ count $>\mathrm{r}$ table, then the instrument or item significantly correlates with the total score (declared valid) and vice versa. An instrument is said to have good and high validity if $0.60<\mathrm{rxy}<0.80$ (Guilford, 1956).

In this study, to find t table of degree of freedom $(\mathrm{df})=(\mathrm{n}-2)=360-2=358$, with a value of $\mathrm{df}=358$ and an alpha value $=0.05$ or $5 \%$, the $\mathrm{r}$ table number is 0.103 .

\section{Table 3}

Validity Test Result

\begin{tabular}{|c|c|c|c|c|}
\hline Variable & Item Questions & $r$ count & r table & Descriptions \\
\hline \multirow{3}{*}{$\begin{array}{c}\text { Perceived Ease } \\
\text { of Use } \\
\left(\mathrm{X}_{1}\right)\end{array}$} & $\begin{array}{l}\text { Information technology can } \\
\text { be very easily learned. }\end{array}$ & 0,848 & 0,103 & Valid \\
\hline & $\begin{array}{l}\text { A person finds it easy and } \\
\text { skilled in using information } \\
\text { technology. }\end{array}$ & 0,847 & 0,103 & Valid \\
\hline & $\begin{array}{l}\text { The operation of } \\
\text { information technology is } \\
\text { relatively easy. }\end{array}$ & 0,850 & 0,103 & Valid \\
\hline \multirow{4}{*}{$\begin{array}{l}\text { Availability of } \\
\text { Islamic } \\
\text { Features } \\
\left(\mathrm{X}_{2}\right)\end{array}$} & $\begin{array}{l}\text { Ease of accessing } \\
\text { information about products } \\
\text { and services. }\end{array}$ & 0,821 & 0,103 & Valid \\
\hline & $\begin{array}{l}\text { Diversity in transaction } \\
\text { services. }\end{array}$ & 0,826 & 0,103 & Valid \\
\hline & $\begin{array}{l}\text { The variety of features } \\
\text { available. }\end{array}$ & 0,791 & 0,103 & Valid \\
\hline & $\begin{array}{l}\text { There is product innovation } \\
\text { in the system. }\end{array}$ & 0,770 & 0,103 & Valid \\
\hline
\end{tabular}




\begin{tabular}{|c|c|c|c|c|}
\hline \multirow{3}{*}{$\begin{array}{c}\text { Perceived Risk } \\
\left(\mathrm{X}_{3}\right)\end{array}$} & There may be a risk of theft. & 0,848 & 0,103 & Valid \\
\hline & $\begin{array}{l}\text { There are need a lot of } \\
\text { money. }\end{array}$ & 0,773 & 0,103 & Valid \\
\hline & $\begin{array}{l}\text { There may be a risk of } \\
\text { fraud. }\end{array}$ & 0,855 & 0,103 & Valid \\
\hline \multirow{4}{*}{$\begin{array}{c}\text { Trust } \\
\text { (Z) }\end{array}$} & Provide information as is. & 0,859 & 0,103 & Valid \\
\hline & Loss of compensation. & 0,816 & 0,103 & Valid \\
\hline & $\begin{array}{l}\text { Security guarantees in } \\
\text { transactions. }\end{array}$ & 0,859 & 0,103 & Valid \\
\hline & $\begin{array}{l}\text { Guarantee of confidentiality } \\
\text { in transactions. }\end{array}$ & 0,824 & 0,103 & Valid \\
\hline \multirow{4}{*}{$\begin{array}{l}\text { Intention } \\
\text { (Y) }\end{array}$} & $\begin{array}{l}\text { There is transactional } \\
\text { intention (a customer wants } \\
\text { to buy a product). }\end{array}$ & 0,807 & 0,103 & Valid \\
\hline & $\begin{array}{l}\text { There is referential intention } \\
\text { (customers refer products to } \\
\text { others). }\end{array}$ & 0,803 & 0,103 & Valid \\
\hline & $\begin{array}{l}\text { There is preferential } \\
\text { intention (customer } \\
\text { prioritizes a product as his } \\
\text { preference). }\end{array}$ & 0,824 & 0,103 & Valid \\
\hline & $\begin{array}{l}\text { There is explorative } \\
\text { intention (customers are } \\
\text { always looking for } \\
\text { information about the } \\
\text { product they are intended } \\
\text { for). }\end{array}$ & 0,765 & 0,103 & Valid \\
\hline
\end{tabular}

Source: Primary data processed, 2020

From the validity test table above, it is known that all indicators used in this study have a correlation coefficient ( $\mathrm{r}$ count) that is greater than the $\mathrm{r}$ table, namely 0.103 . This means that all indicators and questions on each variable in this study are valid so that they are suitable for use as data collectors and can be analyzed for further testing.

\section{Reliability Test}

This test aims to determine the extent to which measuring instruments can be trusted or relied on. Reliability measurement uses the Cronbach alpha technique. A variable will be said to be reliable (trustworthy) if the Cronbach alpha value is $>0.70$ (Ghozali, 2018).

Table 4

Reliability Test Result

\begin{tabular}{lcc}
\hline \multicolumn{1}{c}{ Variable } & $\begin{array}{c}\text { Cronbach } \\
\text { Alpha Value }\end{array}$ & Description \\
\hline Perceived Ease of Use $\left(\mathrm{X}_{1}\right)$ & 0,805 & Reliable \\
\hline Availability of Islamic Features $\left(\mathrm{X}_{2}\right)$ & 0,814 & Reliable \\
\hline
\end{tabular}




\begin{tabular}{lll}
\hline Perceived Risk $\left(\mathrm{X}_{3}\right)$ & 0,767 & Reliable \\
\hline Trust $(\mathrm{Z})$ & 0,860 & Reliable \\
\hline Intention $(\mathrm{Y})$ & 0,811 & Reliable
\end{tabular}

Source: Primary data processed, 2020

From the variable construct reliability testing results used in this study, the Cronbach alpha value was greater than 0.70 . This means that all instruments in this study are reliable so that all question items can be trusted and can be used for further research.

\section{Research Result}

\section{Hypothesis Test Result}

The coefficient of determination (R2) shows the extent of the relationship between the dependent variable and the independent variable or how the independent variable's contribution affects the dependent variable (Bawono, 2006). If the R2 test (coefficient of determination) detects a value of zero (0), then the independent variable's effect on the dependent variable is classified as weak. However, if the R2 test (coefficient of determination) detects the value of one (1), then the independent variable's influence on the dependent variable is strong.

Table 5

Determination Test Result $\left(\mathbf{R}^{2}\right)$

\begin{tabular}{ccc}
\hline Model & $\mathbf{R}$ & R Square \\
\hline 1 & 0,788 & 0,617 \\
\hline Source: Primary data processed, 2020 &
\end{tabular}

From Table 5 above, it can be seen that the correlation coefficient $(\mathrm{R})$ is 0.788 which means that there is a relationship between the dependent variable (intention to use mobile banking) and the independent variable (perceived convenience, availability of Islamic features and perceived risk) of 0.788. The coefficient of determination (adjusted R Square) is 0.617 . This means that $61.7 \%$ of the dependent variable (intention in using mobile banking) can be explained by the independent variable's contribution (perceived convenience, availability of Islamic features and perceived risk). While the rest $(100 \%-61.7 \%=38.3 \%)$ were explained by other causes outside the model.

The F test's function is to determine whether the independent variables simultaneously significantly affect the dependent variable. If the probability is $>0.05$ $(\alpha)$ or F count $<\mathrm{F}$ table, the hypothesis is not proven, then $\mathrm{H}_{0}$ can be accepted. $\mathrm{Ha}$ is rejected if it is done simultaneously (Gujarati, 2001).

Table 6

Simultaneous Significance Test Result (F)

\begin{tabular}{ccc}
\hline Model & F & Sig \\
\hline Regression & 145,816 & 0,000 \\
\hline
\end{tabular}

Source: Primary data processed, 2020

With the ANOVA test or F test, it can be seen that the calculated $\mathrm{F}$ value is 
145.816 with a probability significance value of 0.000 . Because the probability is much smaller than 0.05 , this result means that the regression model can predict the intention to use mobile banking. In other words, the perceived ease of use, the availability of Islamic features and the perception of risk together affect the intention to use mobile banking.

\section{Partial Test (T)}

The T-test shows how much influence one independent variable has on the dependent variable (Ghozali, 2018) if the probability value (significance) $>0.05(\alpha)$ or $\mathrm{T}$ count $<\mathrm{T}$ table means that the hypothesis is not proven, then $\mathrm{H}_{0}$ is accepted, $\mathrm{H}_{\mathrm{a}}$ is rejected.

Table 7

Partial Test Result (T)

\begin{tabular}{lcc}
\hline \multicolumn{1}{c}{ Model } & t & Sig \\
\hline Perceived Ease of Use $\left(\mathrm{X}_{1}\right)$ & 9,979 & 0,000 \\
\hline Availability of Islamic Features $\left(\mathrm{X}_{2}\right)$ & 5,488 & 0,000 \\
\hline Perceived Risk $\left(\mathrm{X}_{3}\right)$ & $-0,263$ & 0,043 \\
\hline Trust $(\mathrm{Z})$ & 6,517 & 0,020 \\
\hline
\end{tabular}

Source: Primary data processed, 2020

Based on table 7 above, it can be much interpretation. First, ease of perception variable $\left(\mathrm{X}_{1}\right)$ has a value of t-count 9.979 and a significance value of $0.000<0.050$ means that it has a positive and significant effect. So, this hypothesis is accepted. Second, the variable availability of Islamic features $\left(\mathrm{X}_{2}\right)$ with a value of $\mathrm{t}$-count of 5.488 and a significance value of $0.000<0.050$ means that it has a positive and significant effect (hypothesis is accepted). Third, the risk perception variable $\left(\mathrm{X}_{3}\right)$ with the t-count value of 0.263 and a significance value of $0.043<0.050$ means that it has a negative and significant effect (hypothesis is accepted). Fourth, the trust variable ( $\mathrm{Z}$ ) with the t-count value of 6,517 and a significance value of $0.020<0.05$ means that it has a positive and significant effect (hypothesis is accepted).

\section{Classic Assumption Test Result}

This test aims to see whether there is a correlation between the independent variables in a regression model. A good regression model shows no correlation between the independent variables.

Table 8

Multicollinearity Test Result

\begin{tabular}{lcc}
\hline \multicolumn{1}{c}{ Model } & Tolerance & VIF \\
\hline Perceived Ease of Use $\left(\mathrm{X}_{1}\right)$ & 0,344 & 2,909 \\
\hline Availability of Islamic Features $\left(\mathrm{X}_{2}\right)$ & 0,360 & 2,775 \\
\hline Perceived Risk $\left(\mathrm{X}_{3}\right)$ & 0,978 & 1,022 \\
\hline Trust $(\mathrm{Z})$ & 0,340 & 2,944 \\
\hline
\end{tabular}




\section{Source: Primary data processed, 2020}

Table 8 shows the multicollinearity test results at the tolerance value of each variable of $0.344 ; 0.360 ; 0.978 ; 0.340$. The VIF value for each variable is $2.909 ; 2,775 ; 1,022$; and 2,944 . Based on the results above, the tolerance value shows no variables with a tolerance value $<0.10$, which means that there is no correlation between more than $95 \%$. The results of calculating the Independent Variance Factor (VIF) also show the same thing; none of the variables has a VIF value $>10$. It can be concluded that there are no symptoms of multicollinearity.

This test is carried out to determine whether there is an inequality of variance from one observation's residuals to another if so, this is called heteroscedasticity (Ghozali, 2013). In this study, to test the heteroscedasticity symptoms using the Park test. If the significance value is below 0.05 , it means heteroscedasticity occurs.

\section{Table 9}

\section{Heteroscedasticity Test Result}

\begin{tabular}{ll}
\hline \multicolumn{1}{c}{ Model } & Sig \\
\hline Perceived Ease of Use $\left(\mathrm{X}_{1}\right)$ & 0,735 \\
\hline Availability of Islamic Features $\left(\mathrm{X}_{2}\right)$ & 0,528 \\
\hline Perceived Risk $\left(\mathrm{X}_{3}\right)$ & 0,253 \\
\hline Trust $(\mathrm{Z})$ & 0,112
\end{tabular}

Source: Primary data processed, 2020

The output results show that the independent variable's parameter coefficient is greater than 0.05 , namely, 0.735 ; by $0.528 ; 0.235$; and 0.112 ; and the equation's heteroscedasticity symptom does not exist. It can be concluded that the regression model occurs homoscedasticity or heteroscedasticity does not occur.

The normality test is used to determine whether each variable is normally distributed or not (Ghozali, 2013). Normal data distributed or cannot be seen in the KolmogorovSmirnov technique if the significance value is above 0.05 , the data distribution is declared to meet the normality assumption. In contrast, if it is below 0.05 , it is interpreted as abnormal.

\section{Table 10}

Normality Test Result

\begin{tabular}{cc}
\hline One-Sample Kolmogorov-Smirnov Test & Unstandardized Residual \\
\hline Asymp. Sig. (2-tailed) & 0,167 \\
Source: Primary data processed, 2020 &
\end{tabular}

The normality test is used to determine whether each variable is normally distributed or not (Ghozali, 2013). Normal data distributed or cannot be seen in the KolmogorovSmirnov technique if the significance value is above 0.05 , the data distribution is declared to meet the normality assumption. In contrast, if it is below 0.05 , it is interpreted as abnormal. 
Linearity test is used to determine whether the observed data's dependent and independent variables are linear or not (Sudjana, 2003). Linearity test can use the ANOVA table in SPSS. Suppose the significance of the deviation from linearity is greater than the significance level $(\alpha)$ of 0.05 . In that case, linear regression can explain the existing variables' effect (Widhiarso, 2010).

\section{Table 11}

\section{Linearity Test Result}

\begin{tabular}{lc}
\hline \multicolumn{1}{c}{ Deviation from Linearity } & Sig \\
\hline Perceived Ease of Use $\left(\mathrm{X}_{1}\right)$ & 0,063 \\
\hline Availability of Islamic Features $\left(\mathrm{X}_{2}\right)$ & 0,551 \\
\hline Perceived Risk $\left(\mathrm{X}_{3}\right)$ & 0,100 \\
\hline Trust $(\mathrm{Z})$ & 0,207 \\
\hline
\end{tabular}

Source: Primary data processed, 2020

Based on the linearity test result, it is known that the significance value of the deviation from linearity of each variable is 0.063 ; $0.551 ; 0.100$; and 0.207 . All of the value is greater than 0.050 ; it can be concluded that there is a linear relationship between perceived convenience, availability of Islamic features, perceived risk, and trust on the intention to use mobile banking.

\section{Path Analysis Test Result}

The path analysis method is used to test the effect of the intervening variables. Path analysis can determine the pattern of relationships between three or more variables and cannot be used to confirm or reject the imaginary causality hypothesis (Ghozali, 2013).

\section{Regression Model 1}

$$
Z=\beta_{o}+\beta_{1} X_{1}+\beta_{2} X_{2}+\beta_{3} X_{3} e
$$

Table 12

Model Summary Test Result 1

\begin{tabular}{cc}
\hline Model & R Square \\
\hline 1 & 0,697 \\
\hline Source: Primary data processed, 2020 &
\end{tabular}

Table 13

\section{Coefficients Test Result 1}

\begin{tabular}{lccc}
\hline \multicolumn{1}{c}{ Model } & \multicolumn{2}{c}{ Unstandardized Coefficients } & \multirow{2}{*}{ Sig } \\
\cline { 2 - 3 } & $\mathbf{B}$ & Std. Error & \\
\hline (Constant) & 1,924 & 0,599 & 0,001 \\
\hline Perceived Ease of Use $\left(\mathrm{X}_{1}\right)$ & 0,421 & 0,068 & 0,000 \\
\hline Availability of Islamic Features $\left(\mathrm{X}_{2}\right)$ & 0,338 & 0,048 & 0,000 \\
\hline Perceived Risk $\left(\mathrm{X}_{3}\right)$ & $-0,103$ & 0,037 & 0.005 \\
\hline
\end{tabular}

Source: Primary data processed, 2020

Based on the table above, the regression equation model is obtained as follows:

$$
Z=1.924+0,421 X_{1}+0,338 X_{2}+(-0,103) X_{3}+e
$$


From model 1, it can be concluded that: The constant 1,924 means that if the perceived convenience variable $\left(\mathrm{X}_{1}\right)$, the availability of Islamic features $\left(\mathrm{X}_{2}\right)$, and the perceived risk $\left(\mathrm{X}_{3}\right)=0$, then the trust $(\mathrm{Z})$ is at 1,924 .

The regression coefficient of perceived ease $\left(\mathrm{X}_{1}\right)$ is 0.421 , which means that each additional one point of perceived convenience $\left(X_{1}\right)$ will increase confidence $(Z)$ by 0.421 times. The regression coefficient of Islamic feature availability $\left(\mathrm{X}_{2}\right)$ is 0.338 , which means that each additional one point of Islamic feature availability $\left(\mathrm{X}_{2}\right)$ will increase trust $(\mathrm{Z})$ by 0.338 times. The risk perception regression coefficient $\left(\mathrm{X}_{3}\right)$ of -0.103 means that each additional one point of risk perception $\left(X_{3}\right)$ will decrease confidence $(Z)$ by 0.103 times.

Based on Table 12 and Table 13 above, it can also be concluded that: Perception of convenience has a significance value of $0.000<0.05$, which means that the perceived convenience variable has a positive and significant effect on trust. The availability of Islamic features has a significance value of $0.000<0.05$, which means that Islamic features' variable availability positively and significantly affects trust. Perception of risk has a significance value of $0.005<0.05$, which means that the risk perception variable has a negative and significant effect on trust. The value of $\mathrm{R}^{2}$ or $\mathrm{R}$ Square found in the Model Summary 1 table is 0.697 , this shows that the contribution of the three independent variables to trust is $69.7 \%$ while the remaining $30.3 \%$ is the contribution of other variables not included in the research. To calculate the value of $\mathrm{e}_{1}$ using the formula $\mathrm{e}_{1}=\sqrt{ }(1-0.697)=0.550$.

\section{Regression Model 2}

$$
\mathbf{Y}=\beta_{o}+\beta_{1} \mathbf{X}_{1}+\beta_{2} \mathbf{X}_{2}+\beta_{3} \mathbf{X}_{3}+\beta_{3} \mathbf{Z}+\mathrm{e}
$$

\section{Table 14}

Model Summary Test Result 2

\begin{tabular}{cc}
\hline Model & R Square \\
\hline 1 & 0,622 \\
\hline
\end{tabular}

Source: Primary data processed, 2020

Table 15

Coefficients Test Result 2

\begin{tabular}{lccc}
\hline \multirow{2}{*}{ Model } & \multicolumn{2}{c}{$\begin{array}{c}\text { Unstandardized } \\
\text { Coefficients }\end{array}$} & \multirow{2}{*}{ Sig } \\
\cline { 2 - 3 } & B & Std. Error & \\
\hline (Constant) & 2,508 & 0,686 & 0,000 \\
\hline Perceived Ease of Use $\left(\mathrm{X}_{1}\right)$ & 0,705 & 0,071 & 0,000 \\
\hline $\begin{array}{l}\text { Availability of Islamic Features } \\
\left(\mathrm{X}_{2}\right)\end{array}$ & 0,297 & 0,054 & 0,000 \\
\hline Perceived Risk $\left(\mathrm{X}_{3}\right)$ & $-0,011$ & 0,043 & 0.043 \\
\hline Trust $(\mathrm{Z})$ & 0,296 & 0,045 & 0,020 \\
\hline
\end{tabular}

Source: Primary data processed, 2020

Based on the table above, the regression equation model is obtained as follows:

$$
Y=2.508+0,705 X_{1}+0,297 X_{2}+(-0,011) X_{3}+0,296 Z+e
$$


From model 2, it can be concluded that: The constant 2.508 means that if the variables of perceived convenience $\left(\mathrm{X}_{1}\right)$, availability of Islamic features $\left(\mathrm{X}_{2}\right)$, perceived risk $\left(\mathrm{X}_{3}\right)$ and trust $(\mathrm{Z})=0$, then the intention to use mobile banking $(\mathrm{Y})$ is at 2.508. The regression coefficient of perceived ease of use $\left(X_{1}\right)$ is 0.705 , which means that each additional one point of perceived usefulness $\left(\mathrm{X}_{1}\right)$ will increase the intention to use mobile banking $(\mathrm{Y})$ by 0.705 times. The regression coefficient for the availability of Islamic features $\left(\mathrm{X}_{2}\right)$ is 0.297 means that every additional one point of Islamic feature availability $\left(\mathrm{X}_{2}\right)$ will increase the intention to use mobile banking ( $\mathrm{Y}$ ) by 0.297 times. The risk perception regression coefficient $\left(\mathrm{X}_{3}\right)$ of -0.011 means that each additional one point of risk perception $\left(\mathrm{X}_{3}\right)$ will reduce intention to use mobile banking $(\mathrm{Y})$ by 0.011 times. The trust regression coefficient $(Z)$ of 0.296 means that each additional one point of trust $(Z)$ will increase intention in using mobile banking $(\mathrm{Y})$ by 0.296 times.

Based on Table 14 and Table 15 above, it can also be concluded that: Perceived convenience has a significance value of $0.000<0.05$, which means that the perceived convenience variable has a positive and significant effect on the intention to use mobile banking. The availability of Islamic features has a significance value of $0.000<0.05$, which means that the variable availability of Islamic features has a positive and significant effect on the intention to use mobile banking. Perception of risk has a significance value of 0.043 $<0.05$, which means that the risk perception variable has a negative and significant effect on the intention to use mobile banking. Trust has a significance value of $0.020<0.05$, which means that the trust variable has a positive and significant effect on the intention to use mobile banking. The value of $\mathrm{R}^{2}$ or $\mathrm{R}$ Square in the Model Summary 2 table is 0.622 . This shows that the three independent variables' contribution to confidence is $62.2 \%$, while the remaining $37.8 \%$ contributes to other variables not included in the research. To calculate the value of $\mathrm{e}_{2}$ using the formula $\mathrm{e}_{2}=\sqrt{ }(1-0,622)=0.614$.

Based on tables 12, 13, 14, 15 then produce the following models: 
Picture 2

Path Analysis Model

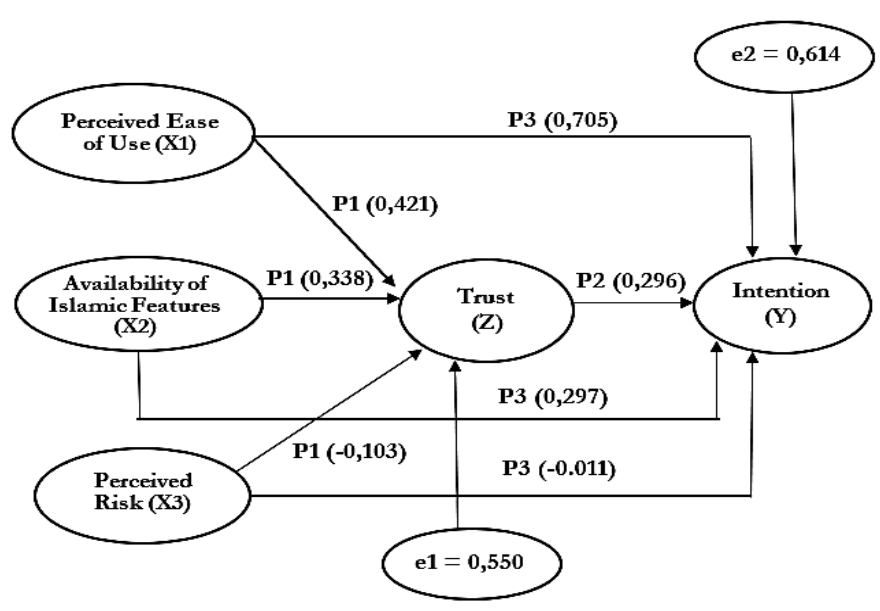

The Effect of Perceived Ease (X1) on Intention to use Mobile Banking (Y) Mediated by Trust (Z)

From the results of the above calculations show that t count (4.769) is greater than t table (1.966), it can be concluded that there is a mediation effect. It can also be seen that the value of the direct effect is 0.705 and the indirect effect is 0.124 . While the total effect is 0.829 . These results also indicate that the perceived convenience indirectly has a significant effect on the intention to use mobile banking. This is confirmed by the $t$ count $>$ t table results, namely $4.769>1.966$ with a significance level of 0.05 . It can be concluded that the mediation coefficient is 0.124 significant, which means that there is a mediation effect. So these results indicate that the perception of convenience indirectly affects the intention in using mobile banking through trust. This proves that trust can mediate the perceived ease of intention to use mobile banking.

The Effect of Availability of Islamic Features $\left(\mathrm{X}_{2}\right)$ on Intention to Use Mobile Banking (Y) Mediated by Trust (Z)

From the results of the calculations indicate that $t$ count $(5,000)$ is greater than $t$ table $(1,966)$, it can be concluded that there is a mediation effect. It can also be seen that the value of the direct effect is 0.297 and the indirect effect is 0.100 . At the same time, the total effect is 0.397 . These results also indicate that indirectly the availability of Islamic features has a significant effect on the intention in using mobile banking. This is confirmed by the $t$ count $>t$ table results, which is $5,000>1,966$ with a significance level of 0.05 . It can be concluded that the mediation coefficient of 0.100 is significant, which means that there is a mediation effect. These results indicate that indirectly the availability of Islamic 
features influences the intention to use mobile banking through trust. This proves that trust can mediate the availability of Islamic features towards the intention to use mobile banking. Effect of Risk Perception ( $\left.\mathrm{X}_{3}\right)$ on Intention to Use Mobile Banking (Y) Mediated by Trust (Z)

From the results of the calculation, it shows that $\mathrm{t}$ count $(-3,000)<\mathrm{t}$ table $(1,966)$, in this case $t$ count is negative, so $t$ count must be smaller in value than $t$ table so it can be concluded that there is a mediating effect.

Besides, it can also be seen that the value of the direct effect is -0.011 and the indirect effect is -0.030 . In contrast, the total effect is -0.041 . These results also indicate that risk perception indirectly has a significant impact on the intention to use mobile banking. This is confirmed by the results of $\mathrm{t}$ count $<\mathrm{t}$ table, namely $-3,000<1,966$ with a significance level of 0.05 . It can be concluded that the mediation coefficient -0.030 is significant, which means that there is a mediation effect. So these results indicate that risk perception indirectly influences the intention to use mobile banking through trust. This proves that trust can mediate risk perceptions of intention in using mobile banking.

\section{Discussion}

\section{The Effect of Perceived Ease on Trust in using Mobile Banking}

Based on the research results, the t-test value of the perceived ease of trust variable shows a value of 6.143 with a significance value of $0.000<0.050$. It can be concluded that the perceived convenience variable $\left(\mathrm{X}_{1}\right)$ has a positive and significant effect on trust $(\mathrm{Z})$, which means that the hypothesis is accepted. Thus, this study shows that if the perception of convenience that students have is good enough, it will further increase students' confidence in the Faculty of Economics and Islamic Business in BSI mobile banking. The elements of ease of use of technology are ease of use, ability to use and so on are proven to be able to influence the perception of ease of customer trust in using internet banking (D. L. Putri \& Fithrie, 2019). In internet banking, if the services and services provided by a bank are perceived as easy, customers will always be encouraged to use these services (Pertiwi \& Adhivinna, 2014).

\section{The Effect of Islamic Features Availability on Trust in using Mobile Banking}

Based on the study results, the t-test value of the variable availability of Islamic features on belief showed a value of 7.013 with a significance value of $0.000<0.050$. It can be concluded that the variable availability of Islamic features $\left(\mathrm{X}_{2}\right)$ has a positive and significant effect on trust $(Z)$, which means that the hypothesis is accepted. Thus, this study shows that if the availability of Islamic features found in BSI mobile banking is good and attractive, it will further increase students' confidence in the Faculty of Economics and Islamic Business in the use of BSI mobile banking. 
The results above align with the research conducted by (Rithmaya, 2016) and (Riyanto, 2018). The research uses the feature availability and trust variables as intervening variables, showing a relationship between the two variables that are positive and significant. Likewise, with various Islamic features, it is possible to increase customers' confidence, especially those who are Muslim. The mobile banking that he will use is a service that can maintain his customers' trust and provide convenience outside of transactions with the bank concerned.

\section{The Effect of Risk Perception on Trust in using Mobile Banking}

Based on the study results, the t-test value of the risk perception variable on trust showed a value of $-2,807$ with a significance value of $0.005<0.050$. It can be concluded that the risk perception variable $\left(\mathrm{X}_{3}\right)$ has a negative and significant effect on trust $(\mathrm{Z})$, which means that the hypothesis is accepted. Thus, this study shows that if the risk perception that students have in using BSI mobile banking is low enough, it will further increase students' confidence in the Faculty of Economics and Islamic Business in BSI mobile banking.

This is in line with the opinion of research conducted by (Jayantari \& Seminari, 2018) which analyzes the effect of risk perception on trust as an intervening variable with negative and significant results. All dimensions of risk perceived by customers, such as functional risk, financial risk, and psychological risk, must be negative for customers to trust the banking technology to be used (C. I. D. Putri \& Sudiksa, 2018).

\section{The Effect of Trust on Intention to Use Mobile Banking}

Based on the research results, the t-test value of the trust variable on the intention to use mobile banking shows a value of 6.517 with a significance value of $0.020<0.050$. It can be concluded that the trust variable $(Z)$ has a positive and significant effect on intention (Y), which means that the hypothesis is accepted. Thus, this study shows that if the Faculty of Economics and Islamic Business students' trust is good enough, it will further increase the intention to use BSI mobile banking.

If the name or image of the bank is already known by the wider community in the banking world, automatically the level of trust that the customer has is very high in the banking sector. It includes mobile banking; if the service image is good, automatically, the level of customer confidence is also good (Saputri, 2018). However, from research (Amelia, 2017) which shows a positive but insignificant value, it is argued that trust does not always attract customers to use mobile banking. If a bank has credibility related to the security factor, customers will no longer consider trusting an underlying factor in selecting a banking product/service. So according to (Habibi \& Zaky, 2015), trust must be built strongly first so that it can influence someone (customer) in using this banking technology.

\section{The Effect of Perceived Ease on Intention to Use Mobile Banking}


Based on the study results, the t-test value of the perceived ease on the intention to use mobile banking variable showed a value of 9.979 with a significance value of $0.000<$ 0.050 . It can be concluded that the perceived convenience variable $\left(\mathrm{X}_{1}\right)$ has a positive and significant effect on intention (Y), which means that the hypothesis is accepted. Thus, this study shows that if the convenience students have in using BSI mobile banking is good enough; it will further increase students' intention in the Faculty of Economics and Islamic Business in using BSI mobile banking.

In the banking world, especially mobile banking, if the services provided by a bank are perceived as easy, customers will always be encouraged to use mobile banking (Maulidiyah, 2017). The perception of ease can be seen in its use which is not difficult; the installation stage is easy, flexible, easy to learn and so on (Pratama, 2019).

\section{The Effect of Islamic Feature Availability on Intention to Use Mobile Banking}

Based on the research results, the t-test value of the Islamic feature availability variable on intention shows a value of 5.488 with a significance value of $0.000<0.050$. It can be concluded that the variable availability of Islamic features (X2) has a positive and significant effect on intention (Y), which means that the hypothesis is accepted. Thus, this study shows that if the availability of Islamic features in BSI mobile banking is good and attractive, it will further increase students' intention in the Faculty of Economics and Islamic Business to use BSI mobile banking.

The availability of features as a bank operational management factor is very important for the success of e-banking (including internet banking and mobile banking) (Poon, 2008). Outstanding features, easy access to information, and product innovation that make mobile banking very attractive to customers (Yulianti, 2019). Likewise, the availability of Islamic features provided by BSI can influence customers intention to use mobile banking services. This is an added value that other banks do not have, especially conventional banking and strongly supports Muslim customers in seeking information.

\section{The Effect of Risk Perception on Intention to Use Mobile Banking}

Based on the study results, the t-test value of the risk perception variable on intention showed a value of -0.263 with a significance value of $0.043<0.050$. It can be concluded that the risk perception variable (X3) has a negative and significant effect on intention (Y), which means that the hypothesis is accepted. Thus, this study shows that if students' risk perception is low enough, it will further increase students' intention in the Faculty of Economics and Islamic Business to use BSI mobile banking.

Risk is one factor that negatively affects customer intention in using mobile banking services (Laraswati, 2016). The greater the risk arising from mobile banking, the less intention in using the service and vice versa in contrast to research conducted by (Aieni \& Purwantini, 2017). His research results indicate that risk perception has a positive effect on 
the intention in using mobile banking. This is because most of the respondents in the study were classified as young people, so they did not care about the risk in making decisions or in other words, they were brave enough to take risks (risk takers) that would arise from the use of technology.

The Effect of Perceived Ease on Intention to Use Mobile Banking through Trust as an Intervening Variable

Based on the Path Analysis test with the Sobel Test, the t count was 4.769, greater than the $t$ table, namely $1.966(4.769>1.966)$ with a significance level of 0.05 . It can be concluded that the mediation coefficient is 0.124 significant, which means that there is a mediation effect. These results also indicate that the perceived convenience indirectly has a significant effect on the intention in using mobile banking through trust, which means that the hypothesis is accepted. This proves that trust can mediate the perceived ease of intention in using mobile banking.

The results above are in line with previous research that perceived convenience $\left(\mathrm{X}_{1}\right)$ has a positive effect on purchase intention $(\mathrm{Y})$ is not directly through a trust $(\mathrm{Z})$ as mediation. (Faradila \& Soesanto, 2016). With the perception of BSI's convenience in using its mobile banking, customers will automatically trust so that they are intention in using the system.

The Effect of Islamic Features Availability on Intention to Use Mobile Banking through Trust as an Intervening Variable

Based on the Path Analysis test with the Sobel Test, it was obtained that t count was 5,000 greater than $t$ table, namely $1.966(5,000>1,966)$ with a significance level of 0.05 . It can be concluded that the mediation coefficient of 0.100 is significant, which means that there is a mediation effect. These results also indicate that indirectly the availability of Islamic features has a significant effect on the intention to use mobile banking through trust, which means that the hypothesis is accepted. This proves that trust can mediate the availability of Islamic features towards the intention to use mobile banking.

The results above are in line with research conducted by (Afifah, 2017), which also examines the availability of features on the intention to use mobile banking through trust. His research indicates an influence between the two variables. The availability of Islamic features provided by BSI can influence customers to believe in the service system, then a feeling of intention in using it will arise.

The Effect of Risk Perception on Intention to Use Mobile Banking through Trust as an Intervening Variable

Based on the Path Analysis test with the Sobel Test, the t count was -3,000 smaller than the $\mathrm{t}$ table, namely $1.966(-3,000<1,966)$ with a significance level of 0.05 . Because $t$ 
count is negative, then, in this case, $t$ must be smaller than $t$ table. It can be concluded that the mediation coefficient -0.030 is significant, which means that there is a mediation effect. These results also indicate that risk perception indirectly significantly affects the intention to use mobile banking through trust, which means that the hypothesis is accepted. This proves that trust can mediate risk perceptions of intention in using mobile banking.

The statement above is in line with previous research that the influence of the convenience, comfort and risk variables intends to use mobile banking with trust as an intervening variable. The results show that each risk variable has a negative influence both on intention. (Bagastia, 2018). Using and trust as the mediating variable. If BSI wants to increase intention to use mobile banking use through trust, banks must minimize the risks posed so that customers have a low-risk perception of the mobile banking services offered.

\section{Conclusions and Suggestions}

The research that has been done can answer the objectives and following all the proposed hypotheses. This study concludes that the variable perception of convenience, availability of Islamic features, and risk perception positively influences trust and intention to use mobile banking. The trust variable can also mediate the three independent variables on the dependent variable, namely intention.

Suggestions for further research are that this research and results can be used as case studies or references regarding lectures. Besides, for further research that examines the variable intention to use mobile banking, this study can be a reference to see other factors that influence the intention to use mobile banking so that more variables can be used. This research's weakness is that the researcher only takes student respondents from the Faculty of Economics and Islamic Business of the State Islamic Institute of Salatiga. Further research is better to take respondents from students or other respondents with a more diverse population. The suggestion from this research for BSI is that it is expected to continue to maintain its quality and performance and innovate in mobile banking to be satisfied when using these services.

\section{REFERENCE}

Afifah, R. (2017). Pengarub manfaat, kemudahan, kepercayaan dan ketersediaan fitur terhadap penggunaan mobile banking bank syariah mandiri. Jakarta: UIN Syarif Hidayatullah.

Ahmad, \& Pambudi, B. S. (2013). Pengaruh Persepsi Manfaat, Persepsi Kemudahan, Keamanan Dan Ketersediaan Fitur Terhadapminat Ulang Nasabah Bank Dalam Menggunakan Internet Banking (Studi Pada Program Layanan Internet Banking Bri). Journal of Chemical Information and Modeling, 53(9), 1689-1699.

Aieni, A. N., \& Purwantini, A. H. (2017). Eksplorasi Penggunaan Mobile Banking: Pendekatan Technology Acceptance Model. Jurnal Analisis Bisnis Ekonomi, 15(1), 8696. 
Amelia, F. R. (2017). Pengaruh Kemudahan, Manfaat, Keamanan, Kenyamanan, dan Kepercayaan Nasabah Terhadap Adopsi Internet Banking pada Bank BNI di Surabaya. In Artikel Ilmiah. Surabaya: Sekolah Tinggi Ilmu Ekonomi Perbanas.

Amijaya, G. R. (2010). Pengaruh Persepsi Teknologi Informasi, Kemudahan, Resiko Dan Fitur Layanan Terhadap Minat Ulang Nasabah Bank Dalam Menggunakan Internet Banking (Vol. 30). Semarang: Universitas Diponegoro.

Ashur, M. (2016). Pengaruh Dukungan Sosial, Persepsi Risiko Dan Interaksi Sosialterhadap Kepercayaan Dan Niat Pembelian Konsumen Pada Media S-Commerce. Jurnal Bisnis Dan Manajemen, 3(1).

Audi, M. F. (2016). Adoption of Mobile Banking Applications in Lebanon. Journal of Internet Banking and Commerce, 1-15.

Bagastia, M. I. (2018). Pengarub Kemudahan, Kenyamanan, dan Risiko terhadap Minat menggunakan Mobile Banking dengan Kepercayaan sebagai Variabel Intervening (Studi Kasus Pada Nasabab Bank BRI Syariah Semarang). Salatiga: IAIN Salatiga.

Bareksa. (2019). Pengguna Internet dan Digital Banking Melonjak Karena Faktor Ini. Bawono, A. (2006). Multivariate Analysis dengan SPSS. Salatiga: Salatiga: STAIN Salatiga Press.

Bisri, C. H. (2001). Penuntun Penyusunan Rencana Penelitian dan Penulisan Skripsi. Jakarta: Raja Grafindo Persada.

Davis, F. D. (1989). Perceived usefulness, perceived ease of use, and user acceptance of information technology. MIS Quarterly: Management Information Systems, 13(3), 319-339.

Djarwanto. (2001). Pokok Pokok Analisa Laporan Kenangan (Cetakan 1). Yogyakarta: BPFE. Faradila, R. S. N., \& Soesanto, H. (2016). Analisis Pengaruh Persepsi Kemudahan Penggunaan dan Persepsi Manfaat terhadap Minat Beli dengan Kepercayaan Sebagai Variabel Intervening (Studi pada Pengunjung Toko Online berrybenka.com di Kalangan Mahasiswa Universitas Diponegoro). Jurnal Studi Manajemen Organisasi, 13(2), 149.

Ghozali, I. (2013). Aplikasi Analisis Multivariate dengan Program IBM SPSS 21 Update PLS Regresi. Semarang: Badan Penerbit Universitas Diponegoro.

Ghozali, I. (2018). Aplikasi Analisis Multivariate dengan Program IBM SPSS 25 (Edisi 9). Semarang: Badan Penerbit Universitas Diponegoro.

Guilford, J. . (1956). Fundamental Statistic in Psychology and Education (3rd ed.). New York: New York: McGraw-Hill Book Company, Inc.

Gujarati, D. (2001). Ekonometri Dasar (Terjemahan). Jakarta: Erlangga.

Gunawan, A. (2014). Aplikasi Technology Acceptance Model Pada Minat Nasabah Untuk Menggunakan Internet Banking. Nominal, Barometer Riset Akuntansi Dan Manajemen, $3(2)$.

Habibi, M., \& Zaky, A. (2015). Pengaruh Kepercayaan, Persepsi Kegunaan, Persepsi 
Kemudahan dan Persepsi Kenyamanan Terhadap Minat Penggunaan Mobile Banking Syariah. Jurnal Ilmiah Mahasiswa FEB. Jurnal Ilmiah Mahasiswa FEB, 3(1), 1-16.

Hadi, S., \& Novi. (2015). FAKTOFaktor yang Mempengaruhi Penggunaan Layanan Mobile Banking. Optimum: Jurnal Ekonomi Dan Pembangunan, 9-13.

Jayantari, I. A. A. U., \& Seminari, N. K. (2018). Peran Kepercayaan Memediasi Persepsi Risiko Terhadap Niat Menggunakan Mandiri Mobile Banking Di Kota Denpasar. EJurnal Manajemen Universitas Udayana, 7(5), 2621.

Jogiyanto. (2007). Sistem Informasi Keperilakuan (Revisi). Yogyakarta: Yogyakarta: Andi Offset.

Laraswati, R. (2016). Pengaruh persepsi risiko, kenyamanan, biaya, dan kepercayaan serta keunggulan relatif terhadap penggunaan mobile banking bagi nasabah Bank Mandiri Surabaya. Surabaya: Sekolah Tinggi Ilmu Ekonomi Perbanas.

Laucereno, S. F. (2019, May). OJK Sebut 2020 Transaksi Perbankan 80\% Pakai Ponsel.

Maulidiyah, S. (2017). Pengaruh Persepsi Manfaat, Kemudahaan Penggunaan, dan Kesesuaian Terhadap Keputusan Menggunakan Mobile Banking Bank Mandiri Di Surabaya. In Artikel Ilmiah. Surabaya: Sekolah Tinggi Ilmu Ekonomi Perbanas.

Mubiyantoro, A., \& Syaefullah. (2013). Pengaruh Persepsi Kegunaan, Persepsi Kemudahan Penggunaan, Persepsi Kesesuaian, dan Persepsi Risiko Terhadap Sikap Penggunaan Mobile Banking. Jurnal Ilmiah Mahasiswa FEB, 1(2), 1-19.

Muslich, M. (2009). KTSP: Pembelajaran Berbasis Kompetensi dan Kontekstual. Malang: Universitas Negeri Malang.

Notoatmodjo, S. (2010). Metodologi Penelitian Kesehatan. Jakarta: Rineka Cipta.

Ong, T. S., Hong, Y. H., Teh, B. H., Soh, P. C. H., \& Tan, C. P. (2014). Factors that affect the adoption of internet banking in Malaysia. International Business Management, 8(2), 5563.

Otoritas Jasa Keuangan. (2015). Bijak Ber-Electronic Banking.

Pertiwi, F., \& Adhivinna, V. V. (2014). Pengaruh Risiko, Manfaat Dan Kemudahan Penggunaan Terhadap Kepercayaan Nasabah Dalam Menggunakan Internet Banking Di Yogyakarta. Jurnal Akutansi Dan Manajemen, 11(9), 421-434.

Poon, W. C. (2008). Users' adoption of e-banking services: The Malaysian perspective. Journal of Business and Industrial Marketing, 23(1), 59-69.

Pratama, A. (2019). Faktor-faktor yang Mempengaruhi Niat dalam Menggunakan Mobile Banking. Jurnal Akun Nabelo: Jurnal Akuntansi Netral, Akuntabel, Objektif, 2, 1-5.

Putri, C. I. D., \& Sudiksa, I. B. (2018). Peran Kepercayaan Dalam Memediasi Pengaruh Persepsi Risiko Terhadap Niat Beli Online Pada Situs Lazada. E-Jurnal Manajemen Universitas Udayana, 7(7), 254165.

Putri, D. L., \& Fithrie, S. (2019). Pengaruh Risiko, Manfaat dan Kemudahan Penggunaan Terhadap Kepercayaan Nasabah dalam Menggunakan Internet Banking di Pekanbaru 
(Studi Kasus pada Nasabah Bank Mandiri). Ikraith Ekonomika, 2(2), 21-28.

Rahmad, A., Astuti, E., \& Riyadi, R. (2017). Pengaruh Kemudahan terhadap Kepercayaan dan Penggunaan SMS Banking (Studi pada Mahasiswa Jurusan Administrasi Bisnis Universitas Brawijaya). Jurnal Administrasi Bisnis S1 Universitas Brawijaya, 43(1), 36-43.

Rithmaya, C. L. (2016). Pengaruh Kemudahan Penggunaan, Kemanfaatan, Sikap, Risiko Dan Fitur Layanan Terhadap Minat Ulang Nasabah Bank Bca Dalam Menggunakan Initernet Banking. Jurnal Riset Ekonomi Dan Manajemen, 16(1), 160.

Riyanto. (2018). Analisis Pengarub Persepsi Kegunaan, Kemudahaan dan Ketersediaan Fitur Terbadap

Minat Menggunakan Mobile Banking dengan Kepercayaan sebagai Variabel Intervening) (Studi Kasus pada Mahasiswa FEBI IAIN Salatiga). Salatiga: Institut Agama Islam Negeri Salatiga.

Rousseau, J. J. (2009). DU Contract Social (Perjanjian Sosial) (Cetakan 2). Jakarta: Visimedia. Saputri, L. (2018). Pengaruh Persepsi Manfaat, Persepsi Kemudahan Penggunaan dan

Persespi Risiko terhadap Minat Masyarakat Menggunakan Fasilitas Electronic Banking Bank Syariah dengan Kepercayaan sebagai Variabel Intervening. Salatiga: Institut Agama Islam Negeri Salatiga.

Sudjana. (2003). Teknik Regresi dan Korelasi bagi Para Peneliti. Bandung: Bandung: Tarsito.

Sugiyono. (2010). Metode Penelitian Pendidikan Pendekatan Kuantitatif, kualitatif, dan R\&D. Bandung: Alfabeta.

Sunyoto, D. (2016). Metodologi Penelitan Akuntansi (Cetakan 2). Bandung: PT. Refika Aditama Anggota Ikapi.

Tampubolon, N. (2015). Bijak Ber E-Banking. Bijak Ber E-Banking.

Thompson, R. L., Higgins, C. A., \& Howell, J. M. (1991). Personal computing: Toward a conceptual model of utilization. MIS Quarterly: Management Information Systems, 15(1), 125-142.

Widhiarso, W. (2010). Uji Linieritas Hubungan. Yogyakarta: Universitas Gadjah Mada.

Williams, S. (2011). Building a Discipline to Drive Digital Banking Strategy - Gonzobanker. Yulianti, R. (2019). Pengaruh Kemudahan Penggunaan, Manfaat, Ketersediaan Fitur, Biaya, dan Risiko terhadap Penggunaan Mobile Banking di BNI Syariah KC Surakarta. Surakarta: Institut Agama Islam Negeri Surakarta.

Zuriah, N. (2009). Metodologi Penelitian Sosial dan Pendidikan Teori Aplikasi (Cetakan 3). Jakarta: PT Bumi Aksara. 